\title{
ANTIMICROBIAL AND GENOTOXIC ACTIVITY OF NOVEL RUTHENIUM(III) COMPLEX WITH $N$-PHENYL-5-NITROSALICYLIDENEIMINE
}

\author{
N. Ljubijankić1, ${ }^{1,}$, S. Begić1, A. Ljubović-Dedeić2, M. Stanković ${ }^{3}$, \\ I. Salimović-Bešićc ${ }^{2}$ M. Jadranin ${ }^{4}$, B. Bencun ${ }^{1}$ and S. Ljubijankić ${ }^{5}$ \\ ${ }^{1}$ Department of Chemistry, Faculty of Science, University of Sarajevo, \\ 71000 Sarajevo, Bosnia and Herzegovina \\ ${ }^{2}$ Unit of Clinical Microbiology, Clinical Centre University of Sarajevo, \\ 71000 Sarajevo, Bosnia and Herzegovina \\ ${ }^{3}$ Institute of Chemistry, Technology and Metallurgy, University of Belgrade, \\ 11000 Belgrade, Serbia \\ ${ }^{4}$ Faculty of Chemistry, University of Belgrade, 11000 Belgrade, Serbia \\ ${ }^{5}$ Faculty of Health Studies, University of Bihać, 77000 Bihać, Bosnia and Herzegovina \\ *E-mail: nevzetalj@gmail.com
}

\begin{abstract}
In this study, novel hexa coordinated ruthenium(III) complex of the type $\mathrm{Na}\left[\mathrm{RuCl}_{2} \mathrm{~L}_{2}\right.$ )] (where $\mathrm{L}=$ monobasic bidentate Schiff base derived from the condensation of 5-nitrosalicyladehyde with aniline) has been synthesized and characterized by electrospray ionization time-of-flight mass spectrometry, infrared spectroscopy and ultraviolet/visible spectrophotometry. Schiff base $N$-phenyl-5-nitrosalicylideneimine is coordinated to the ruthenium via imine nitrogen and phenolic oxygen. Mass spectra showed molecular ion ( $\left.\mathrm{M}^{-}\right)$at $\mathrm{m} / \mathrm{z} 653.9641$ which corresponds to $\left[\mathrm{C}_{26} \mathrm{H}_{18} \mathrm{Cl}_{2} \mathrm{~N}_{4} \mathrm{O}_{6} \mathrm{Ru}\right]^{-}$. The in vitro antimicrobial properties of the Schiff base and the complex were tested by micro-dilution technique and agar plate assay for determination of minimum inhibitory concentration (MIC) and minimum bactericidal concentration (MBC). The compounds showed a higher antibacterial activity against tested Gram-positive bacteria (Staphylococcus aureus ATCC 33591 and ATCC 29213), whereas against the Gram-negative bacteria (Pseudomonas aeruginosa ATCC 27853, Escherichia coli ATCC 25922, Klebsiella pneumoniae ATCC 700603) were ineffective. The genotoxic effects of $\mathrm{Ru}(\mathrm{III})$ complex were investigated using the Cytokinesis Block Micronucleus (CBMN) assay in human lymphocytes cultures. The cell culture treated with the complex at a concentration of $3.7 \mu \mathrm{g} / \mathrm{mL}$ exhibit the most prominent effect of decreasing the frequency of micronucleus for $44 \%$, while at the concentrations of 1.5 and $7.4 \mu \mathrm{g} / \mathrm{mL}$ effect is slightly lower (40\%), compared to the control cell culture.
\end{abstract}

Keywords: Ruthenium(III) complex, $N$-phenyl-5-nitrosalicylideneimine, Minimum inhibitory concentration, Minimum bactericidal concentration, Cytokinesis block micronucleus assay

@ $\operatorname{RASĀYAN}$. All rights reserved

\section{INTRODUCTION}

Over the past few decades, metal complexes containing Schiff bases have attracted a significant attention in coordination chemistry. The reasons for this lies in Schiff base ligands as a result of their ability to stabilize numerous different metals in a variety of oxidation states, simple preparation, stability, structural diversity as well as a wide range of applications. ${ }^{1-5}$ A huge number of Schiff base metal complexes have been synthesized and extensively studied in a broad diversity of fields as biochemical, antitumor and antimicrobial agents. ${ }^{6-11}$ The azomethine linkage of the Schiff bases is crucial for its biological activity. Among the Schiff base metal complexes, ruthenium complexes have been broadly explored and their therapeutic potentials have been the subject of intensive research during the last decades. ${ }^{12}$ They are

Rasayan J. Chem., 11(4), 1511-1518(2018)

http://dx.doi.org/10.31788/RJC.2018.1145021

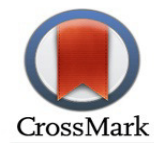


reported to have antitumor, antiviral, antifungal, antibacterial, antioxidant activity. ${ }^{13-16}$ Ruthenium(III) Schiff base complexes exhibited better antibacterial activity than their ligands, Schiff bases, against Esherichia coli, Bacillus subtilis, Staphylococcus aureus. ${ }^{15,11}$ The biological activity of the potential drug in the pre-clinical investigations should be comprehensively examined with the aim to obtain as much information as possible about its therapeutic and side effects in the living organism. ${ }^{17,18}$ In the last decade, there is a remarkable increase of bacterial pathogens that present multidrug resistance than currently available antimicrobial agents. Therefore, the development of new antimicrobial strategies and antibacterial agents is an active area of research. ${ }^{19,20}$ A relatively small number of complexes containing Schiff base derived from 5-nitrosalicylaldehyde is stored in the Cambridge Structural Database (CSD). ${ }^{21}$ The syntheses of ruthenium(III) Schiff base complexes are in focus of interest because of their wide range of applications. ${ }^{22}$ Besides the estimation of antimicrobial activity of new complex compounds as potential therapeutic agents, the detection and the evaluation of genotoxic effects are of vital importance. According to our knowledge, genotoxic activities of metal complexes have been very little described by using cytokinesis block micronucleus (CBMN) assay in human lymphocytes. The genotoxic activities of copper(II), cadmium(II) and lead(II) complexes with macrocyclic ligands have been described by Beynek and others, while organometallic compounds of tin(II) and tin(IV) by Damati and others. ${ }^{23,24}$ In our previous paper, we studied in vitro effects of the $\mathrm{Ru}(\mathrm{III})$ thiosemicarbazone complexes on human lymphocytes using the CBMN assay. ${ }^{18}$ The CBMN assay in peripheral human lymphocytes is well established cytogenetic technique and is developed to score micronuclei ( $\mathrm{MN})$ in different nucleated cell types in vitro or in vivo. ${ }^{25,26}$ The analysis of micronuclei $(\mathrm{MN})$ in cultured lymphocytes is frequently used as a preferred method to biomonitor human exposure to genotoxic agents. Micronuclei are cytoplasmatic chromatin masses that occurred like small nuclei as a result of lesions/adducts at the level of DNA or chromosomes, or at the level of proteins directly or indirectly involved in chromosome segregation (e.g. tubulin). The CBMN assay allows micronuclei that have completed one nuclear division to be specifically scored in binucleated cells after blocking cytokinesis by addition of cytochalasin B (Cyt B) during the targeted mitosis. ${ }^{27}$ Cyt B allows karyokinesis (a division of the cell nucleus) but also is an inhibitor of the mitotic spindle that prevents cell division (cytokinesis). ${ }^{28}$ The simplicity, rapidity, sensitivity and versatility of the in vitro micronucleus test in different cell types make it a valuable tool for genotoxicity screening. ${ }^{24}$ In view of the wide interest in the chemistry of ruthenium, the present article is a continuation of our research activities on the synthesis, characterization and biological properties of the new ruthenium(III) Schiff base complex.

\section{Materials and methods}

\section{EXPERIMENTAL}

The chemicals used in this study were all of the analytical grade purity and were used as received. The infrared spectra were acquired using $\mathrm{KBr}$ disc technique on Perkin Elmer Spectrum BX FTIR System over the range $4000-400 \mathrm{~cm}^{-1}$. The electronic absorption spectra of the samples were measured in dichloromethane solution using Perkin Elmer UV/Visible lambda 35 spectrophotometers in the range of $200-700 \mathrm{~nm}$. The mass spectra of the complex were recorded using Agilent 6210 Time-of-Flight LC/MS system (Agilent Technologies, Santa Clara, California, USA) via an electro spray ionization (ESI) interface (ESI-ToF-MS). Nitrogen was used as drying gas $(12 \mathrm{~L} / \mathrm{min})$ and nebulizing gas at $350^{\circ} \mathrm{C}(45$ psi). The OCT RF and capillary voltage were set to $250 \mathrm{~V}$ and $4.0 \mathrm{kV}$, respectively. The voltages applied to the fragmentor and skimmers were $140 \mathrm{~V}$ and $60 \mathrm{~V}$, respectively. Scanning was performed from 100 to $2000 \mathrm{~m} / \mathrm{z}$ (mass-to-charge ratio). The compound was dissolved in the acetonitrile (concentration of 1 $\mathrm{mg} / \mathrm{mL}$ ), and a direct injection of $5 \mu \mathrm{L}$ sample was conducted by 1200 Series HPLC (Agilent Technologies, Waldbronn, Germany) without a separation column, using isocratic mobile phase: $50 \%$ acetonitrile and $50 \%$ of $0.2 \%$ formic acid in water (v/v) at flow rate: $0.2 \mathrm{ml} / \mathrm{min}$.

\section{Synthesis of the Schiff base, $\mathrm{L}$}

The Schiff base, $N$-phenyl-5-nitrosalicylideneimine, hereinafter L, was prepared by adding an ethanolic solution of 5-nitrosalicylaldehide ( $4 \mathrm{mmol} ; 0.6685 \mathrm{~g}$ ) to an ethanolic solution of aniline (4 mmol; 365 $\mu \mathrm{L})$. The mixture was refluxed for one hour at $65^{\circ} \mathrm{C}$. The precipitated crystals were recrystallized from hot ethanol and then dried under vacuum. The purity was checked by IR spectroscopy. 


\section{Synthesis of $\mathrm{Ru}(\mathrm{III})$ Complex, $\left.\mathrm{Na}\left[\mathrm{RuCl}_{2} \mathrm{~L}_{2}\right)\right]$}

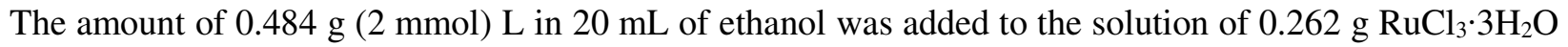
$(1 \mathrm{mmol})$ in $10 \mathrm{~mL}$ of ethanol and refluxed for three hours at $70^{\circ} \mathrm{C}$. The resulting solution was reduced to about $15 \mathrm{~mL}$ by rotary vacuum evaporation. After the solution was left overnight aqueous solution $(1 \mathrm{~mL})$ $\mathrm{NaCl}(0.117 \mathrm{~g} ; 2 \mathrm{mmol})$ was added to precipitate the complex. The dark green partly crystalline compound was filtered off, washed with ethanol and ether, and dried in vacuum.

$\mathrm{Na}\left[\mathrm{RuCl}_{2} \mathrm{~L}_{2}\right]$

ESI-ToF MS m/z: $\left[\mathrm{C}_{26} \mathrm{H}_{18} \mathrm{Cl}_{2} \mathrm{~N}_{4} \mathrm{O}_{6} \mathrm{Ru}\right]^{-}$653.9641; FT-IR L $\left(\mathrm{KBr}, \mathrm{cm}^{-1}\right): 1621 \mathrm{~s}\left[v_{\mathrm{s}}(\mathrm{C}=\mathrm{N})\right], 1290 \mathrm{~s}\left[v_{\mathrm{s}}(\mathrm{C}-\right.$ $\left.\left.\mathrm{O}_{\text {phen }}\right)\right]$; FT-IR Na[RuCl $\left.\mathrm{L}_{2}\right]\left(\mathrm{KBr}, \mathrm{cm}^{-1}\right): 1603 \mathrm{~s}\left[v_{\mathrm{s}}(\mathrm{C}=\mathrm{N})\right], 1313 \mathrm{~s}\left[v_{\mathrm{s}}\left(\mathrm{C}-\mathrm{O}_{\text {phen }}\right)\right], 543 \mathrm{~s}\left[v_{\mathrm{s}}(\mathrm{Ru}-\mathrm{N}), 487 \mathrm{~s}\right.$ $\left[v_{\mathrm{s}}(\mathrm{Ru}-\mathrm{O})\right]$

\section{Antimicrobial Activity}

Antimicrobial activity was tested on pathogens collected from the Unit of Clinical Microbiology of the Clinical Centre University of Sarajevo. The in vitro antimicrobial activities of the ligand and $\mathrm{Ru}(\mathrm{III})$ complex were tested by micro-dilution technique and agar plate assay for determination of minimum inhibitory concentration (MIC) and minimum bactericidal concentration (MBC) according to the literature procedure. ${ }^{29,30}$ Complex and ligand were dissolved in $97 \%$ dimethyl sulfoxide (DMSO) to a stock concentration of $20 \mathrm{mg} / \mathrm{mL}$ and then diluted into the initial concentration of $512 \mu \mathrm{g} / \mathrm{mL}$ in sterile Tryptic Soy Broth. Serial two-fold dilutions of decreasing concentration starting with $256 \mu \mathrm{g} / \mathrm{mL}$ and ending with $0.25 \mu \mathrm{g} / \mathrm{mL}$ of compounds were obtained by pipetting $50 \mu \mathrm{L}$ of the compound solution in sterile 96-well microtiter plates with $50 \mu \mathrm{L}$ of broth in each well. Antimicrobial susceptibility testing was performed against referral strains of Gram-positive bacteria Staphylococcus aureus ATCC 33591 and ATCC 29213 and Gram-negative bacteria Pseudomonas aeruginosa ATCC 27853, Escherichia coli ATCC 25922 and Klebsiella pneumoniae ATCC 700603. An inoculum of each bacterial strain was made up to a turbidity equivalent of $0.5 \mathrm{McFarland}$ standard prior to testing from colonies of a pure strain culture. The volume of $50 \mu \mathrm{L}$ inoculum was dispensed in each well containing $50 \mu \mathrm{L}$ of broth and diluted compound. Final volume per well was $100 \mu \mathrm{L}$. The same testing was performed with positive controls containing Gentamycin and Vancomycin instead of studied compounds. Inoculated compound-free broth with diluents was used as a negative control. After primary incubation at $35-37^{\circ} \mathrm{C}$ for 22 hours, MIC results were read. The MIC endpoint was the lowest concentration of antibiotic/compound that did not exhibit visible microorganism growth. After MIC test has been completed, subculturing on selective and differential agar plate from all dilutions with no visible bacterial growth was done. The first dilution without bacterial growth observed on plate represented MBC. For Staphylococcus strains, subculturing was done to mannitol-salt agar (MSA), while for other strains, MacConkey agar plates were used, both not containing the test compounds. After incubation at $35-37^{\circ} \mathrm{C}$ for 22 hours, $\mathrm{MBC}$ results were recorded in $\mathrm{cfu} / \mathrm{mL}$.

\section{Cytokinesis-Block Micronucleus (CBMN) Assay, Statistics and Index Calculation}

The experiments were performed on peripheral blood lymphocytes obtained from five healthy nonsmoking female volunteers not undergoing any drugs or other substances treatment. The volunteers were aware of this study that was conducted according to the code of ethics of the World Medical Association (Helsinki Declaration of 1964, as revised in 2002) (11 $^{31}$ and gave permission for using their blood for this experiment. Two 5-mL aliquots of blood were collected from each volunteer and stored in heparinised sterile tubes (Becton Dickinson, Bradford, MA). The blood samples were obtained at the Medical Unit concerning a safety protocol blood/borne pathogen/biohazard according to current Health and Ethical regulations in Serbia, Law on Health Care. ${ }^{32}$ The culture lymphocytes were treated with the complex. Three concentrations of the complex were used, i.e. $1.5 \mu \mathrm{g} / \mathrm{mL}, 3.7 \mu \mathrm{g} / \mathrm{mL}$ and $7.4 \mu \mathrm{g} / \mathrm{mL}$, and it was not added to the one cell culture which was used as the control. As a positive control Amifostine WR-2721 (98\%, S-2[3-aminopropylamino]-ethylphosphothioic acid, Marligen-Biosciences, USA) at concentration of $1.0 \mu \mathrm{g} / \mathrm{mL}$ was used. They were added to the cultures $25 \mathrm{~h}$ after phytohaemagglutinin (PHA) stimulation and life until harvest and incubated in a thermostat at $37^{\circ} \mathrm{C}$. After treatment with the tested 
complex for $19 \mathrm{~h}$, all cultures were rinsed with a pure medium, transferred into $5 \mathrm{~mL}$ fresh RPMI 1640 medium (RPMI 1640 Medium + GlutaMAX + 25 mM HEPES; Invitrogen-Gibco-BRL, Vienna, Austria) and incubated for additional $72 \mathrm{~h}$. Circa $2 \times 10^{6}$ blood lymphocytes were set up in $5 \mathrm{~mL}$ RPMI-1640 medium supplemented with $15 \%$ of calf serum and $2.4 \mu \mathrm{g} / \mathrm{mL}$ of phytohaemaglutinin (Invitrogen-GibcoBRL). Three concentrations of the tested complex were added to the samples one hour after initiating the cell stimulation. The incidence of spontaneously occurring $\mathrm{MN}$ in control samples was scored. For MN preparation, the cytokinesis-block micronucleus assay was performed as previously described. ${ }^{33,34}$ At least 1000 binucleated (BN) cells per sample were scored, registering $\mathrm{MN}$ according to the literature criteria. ${ }^{33,35}$ After $44 \mathrm{~h}$ of culture, $6 \mu \mathrm{g} / \mathrm{mL}$ of cytochalasin B (Invitrogen-Gibco-BRL, Vienna, Austria) was poured into each sample and allowed to incubate another $24 \mathrm{~h}$. After $72 \mathrm{~h}$ of culture, the cells were washed with $0.9 \% \mathrm{NaCl}$ (Merck, Sharp and Dohme GMBH, Vienna, Austria), collected by centrifugation and treated with a hypotonic solution $\left(56 \% \mathrm{KCl}+0.9 \% \mathrm{NaCl}\right.$ mixed in equal volumes) at $37^{\circ} \mathrm{C}$. The cell suspension was prefixed in methanol/acetic acid in a ratio of $3: 1$, washed three times with fixative, and dropped onto a clean slide. ${ }^{30}$ The slides were air dried and stained with alkaline Giemsa 2\% (SigmaAldrich, Vienna, Austria). At least 1000 binucleated (BN) cells per sample were scored, registering MN according to the criteria described in the literature. ${ }^{33,35}$ In order to determine possible cytotoxic effects, the cytokinesis-block proliferation index (CBPI) was calculated as suggested by Surralles and others. ${ }^{36}$ CBPI is given by the equation: $\mathrm{CBPI}=[(M 1+2 M 2+3(M 3+M 4)] / \mathrm{N}$, where $M 1-4$ represent the numbers of cells with one, two, three and four nuclei, respectively, and $\mathrm{N}$ is the total number of cells scored. For the analysis of MN, only binucleated cells with well-preserved cytoplasm were scored (under a light microscope with a $40 \times 10$ magnification) by following the criteria given in the HUMAN project website (http://www.humn.org). ${ }^{33}$ The number of binucleated cells with 1, 2, 3 or more MN was then tabulated. The data for each treatment were expressed as the frequency of MN per 1000 binucleated cells. The statistical analysis of the obtained data was conducted with the use of the Origin software package version 7.0. The statistical significance of the difference between the data pairs was evaluated by analysis of variance (One way ANOVA) followed by the Tukey test. In all experiments, we considered $\mathrm{p}<0.01$ and $\mathrm{p}<0.05$ to indicate statistical significance. The index calculating is presented as the $\%$ of change comparing different groups.

\section{Synthesis and Spectral Characterization}

\section{RESULTS AND DISCUSSION}

The Schiff base ligand was synthesized according to the general literature procedure by condensing 5nitrosalicyladehyde and aniline. Schiff base, $\mathrm{L}$ react with $\mathrm{RuCl}_{3}$ in $2: 1$ molar ratio in absolute ethanol to afford stable ruthenium(III) complex, sodium dichlorobis[ $N$-phenyl-5-nitrosalicylideneiminato$N, O$ ruthenate(III), hereinafter $\left.\mathrm{Na}_{2} \mathrm{RuCl}_{2} \mathrm{~L}_{2}\right]$ (Fig.-1). Novel ruthenium(III) bis-Schiff base anionic complex derived from 5-nitrosalicylaldehyde and aniline is stable in the air, soluble in most common polar organic solvents and insoluble in non-polar organic solvents and water.

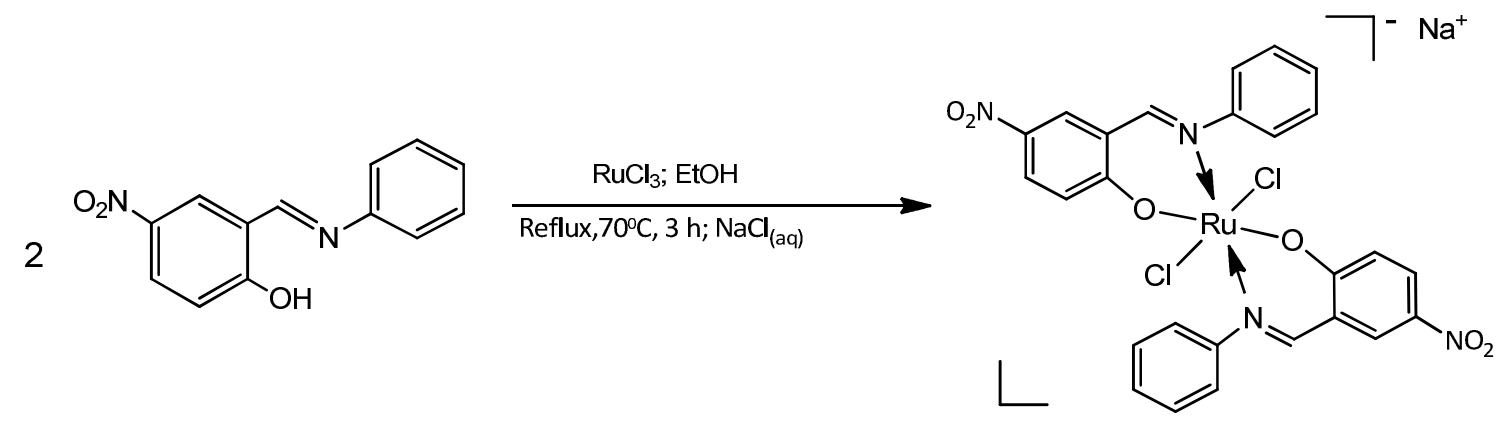

Fig.-1: Preparation Scheme for $\mathrm{Na}\left[\mathrm{RuCl}_{2} \mathrm{~L}_{2}\right]$

The Schiff base ligand has been characterized by infrared and electronic spectroscopy, while the complex has been characterized by mass spectrometry, UV/Vis and infrared spectroscopy. The high-resolution mass spectrum of the complex was recorded in the negative ESI ionization mode, where the anionic component was detected as $\left[\mathrm{C}_{26} \mathrm{H}_{18} \mathrm{Cl}_{2} \mathrm{~N}_{4} \mathrm{O}_{6} \mathrm{Ru}\right]^{-}$with $\mathrm{m} / \mathrm{z}$ (100\%): 653.9641. The characteristic infrared 


\section{RASĀYAN J. Chem.}

Vol. 11 | No. 4 |1511 - 1518| October - December | 2018

frequencies and electronic spectral data of ligand and complex are listed in Table- 1 . A strong band in the free ligand observed at $1621 \mathrm{~cm}^{-1}$ is the characteristic of the azomethine $(-\mathrm{HC}=\mathrm{N})$ group. After coordination of the nitrogen to the ruthenium, this band is shifted to $1603 \mathrm{~cm}^{-1}$. This shift toward lower frequency for $18 \mathrm{~cm}^{-1}$ indicating the coordination of ligand via azomethine nitrogen, while electron density in the azomethine group is reduced. ${ }^{2}$ An intense band at $1290 \mathrm{~cm}^{-1}$ in the free ligand assigned to phenolic C-O group has shifted to higher frequency $\left(1313 \mathrm{~cm}^{-1}\right)$ after complexation what it proves that the phenolic group coordinates to ruthenium atom after deprotonation. Coordination of the ligand with the ruthenium as the metal center was further substantiated by the appearance of two new weak bands at 543 and $487 \mathrm{~cm}^{-1}$ which could be assigned to $v(\mathrm{Ru}-\mathrm{N})$ and $v(\mathrm{Ru}-\mathrm{O})$, respectively. The electronic spectra of the ligand and $\mathrm{Ru}(\mathrm{III})$ complex were recorded in dichloromethane in the range $700-220 \mathrm{~nm}$. The electronic spectrum of the free Schiff base display absorption bands within the range $230-350 \mathrm{~nm}$ due to $\pi \rightarrow \pi^{*}$, $\mathrm{n} \rightarrow \pi^{*}$ and intraligand transitions. ${ }^{11}$ The $\mathrm{Ru}(\mathrm{III})$ complex shows three bands. The absorption bands below $360 \mathrm{~nm}$ are ligand-centered $\left(\pi \rightarrow \pi^{*}\right.$ and $\left.\mathrm{n} \rightarrow \pi^{*}\right)$ transitions. ${ }^{2,11}$ The weak broad band centered at $625 \mathrm{~nm}$ have been assigned to the $\mathrm{d} \rightarrow \mathrm{d}$ transition of the $\mathrm{Ru}(\mathrm{III})$ ion $\left({ }^{2} \mathrm{~T}_{2 \mathrm{~g}} \rightarrow{ }^{2} \mathrm{~A}_{2 \mathrm{~g}}\right)$ which is in agreement with assignments made for similar ruthenium(III) complexes. ${ }^{22}$ The nature of the electronic spectrum supports an octahedral geometry of the $\mathrm{Ru}(\mathrm{III})$ ion in the complex.

Table-1: Characteristic IR $\left(\mathrm{cm}^{-1}\right)$ and Electronic (nm) Bands of the Ligand and its Complex

\begin{tabular}{l|c|c|c|c|c}
\hline \multirow{2}{*}{ Ligand/Complex } & $v(\mathrm{C}=\mathrm{N}-\mathrm{H})$ & $v(\mathrm{C}-\mathrm{OH})$ & $v(\mathrm{Ru}-\mathrm{N})$ & $v(\mathrm{Ru}-\mathrm{O})$ & $\lambda$ \\
\cline { 2 - 6 } & $\mathrm{cm}^{-1}$ & $\mathrm{~cm}^{-1}$ & $\mathrm{~cm}^{-1}$ & $\mathrm{~cm}^{-1}$ & $\mathrm{~nm}$ \\
\hline $\mathrm{L}$ & 1621 & 1290 & - & - & $232,270,350$ \\
\hline $\mathrm{Na}\left[\mathrm{RuCl}_{2} \mathrm{~L}_{2}\right]$ & 1603 & 1313 & 543 & 487 & $245,351,625$ \\
\hline
\end{tabular}

\section{Antimicrobial Activity}

The results of antimicrobial activity were compared to the corresponding positive controls. The $\mathrm{Ru}$ (III) complex showed equally high antibacterial activity (MIC $16 \mu \mathrm{g} / \mathrm{mL}$ ) in tested Gram-positive bacteria $S$. aureus ATCC 29213 (MSSA) and ATCC 33591 (MRSA). Subsequently, the ligand demonstrated higher values of MICs then complex, differing in one or two double dilutions (Table-2). However, their antibacterial activity was lower in comparison to the positive controls. Against the Gram-negative bacteria ( $P$. aeruginosa ATCC 27853, E. coli ATCC 25922 and $K$. pneumoniae ATCC 700603), both complex and ligand were ineffective, starting with their initial dilution of $256 \mu \mathrm{g} / \mathrm{mL}$ (Table-2). MBC confirmed the MIC results for each tested compound and bacterial strain.

Table-2: Minimum Inhibitory Concentration (MIC) and Minimum Bactericidal Concentration (MBC) of Tested $\mathrm{Na}\left[\mathrm{RuCl}_{2} \mathrm{~L}_{2}\right]$ and $\mathrm{L}$

\begin{tabular}{l|c|c|c|c|c|c|c|c}
\hline \multirow{2}{*}{ Referral strain } & \multicolumn{2}{|c|}{$\mathbf{N a}\left[\mathbf{R u C l}_{2} \mathbf{L}_{2}\right]$} & \multicolumn{2}{|c|}{$\mathbf{L}$} & \multicolumn{2}{|c|}{ Gentamycin } & \multicolumn{2}{|c}{ Vancomycin* } \\
\cline { 2 - 10 } & $M I C$ & $M B C$ & $M I C$ & $M B C$ & $M I C$ & $M B C$ & $M I C$ & $M B C$ \\
\cline { 2 - 10 } & \multicolumn{2}{|c|}{$(\mu g / m L)$} & \multicolumn{2}{|c|}{$(\mu g / m L)$} & \multicolumn{2}{|c|}{$(\mu g / m L)$} & \multicolumn{2}{|c}{$(\mu g / m L)$} \\
\hline $\begin{array}{l}\text { Staphylococcus aureus } \\
\text { ATCC 29213 (MSSA) }\end{array}$ & 16 & 16 & 32 & 32 & 4 & 4 & 4 & 4 \\
\hline $\begin{array}{l}\text { Staphylcoccus aureus } \\
\text { ATCC 33591 (MRSA) }\end{array}$ & 16 & 16 & 64 & 64 & 8 & 8 & 4 & 4 \\
\hline $\begin{array}{l}\text { Escherichia coli } \\
\text { ATCC 25922 }\end{array}$ & 256 & 256 & 256 & 256 & 4 & 4 & $/$ & $/$ \\
\hline $\begin{array}{l}\text { Klebsiella pneumoniae } \\
\text { ATCC 700603 }\end{array}$ & 256 & 256 & 256 & 256 & 8 & 8 & $/$ & $/$ \\
\hline $\begin{array}{l}\text { Pseudomonas aeruginosa } \\
\text { ATCC 27853 }\end{array}$ & 256 & 256 & 256 & 256 & 2 & 2 & $/$ & $/$ \\
\hline
\end{tabular}

*Vancomycin is not the therapy of choice for Gram-negative bacteria and was not tested on them during the study. 


\section{The Results of Cytokinesis-Block Micronucleus Assay}

The synthesized $\mathrm{Ru}(\mathrm{III})$ complex was tested for in vitro protective effect on chromosome aberrations in peripheral human lymphocytes using the cytochalasin-B blocked micronucleus (MN) assay at concentrations of $1.5,3.7$ and $7.4 \mu \mathrm{g} / \mathrm{mL}$. The frequencies and distribution of $\mathrm{MN}$ in human lymphocytes were scored, and the results are given in Table-3. Amifostin (WR-2721), a phosphorylated aminothiol pro-drug, which is an analog of cysteamine, was used as a positive control. ${ }^{37}$ The cell cultures treated with amifostine at concentrations of $1.0 \mu \mathrm{g} / \mathrm{mL}$ led to a decrease of $18 \%$ in the MN frequency compared to control cell cultures. The most prominent effect $(p<0.01)$ of decreasing the frequency of MN by $44 \%$, when compared with the control cell cultures, exhibited the cell cultures treated with the tested $\mathrm{Na}\left[\mathrm{RuCl}_{2} \mathrm{~L}_{2}\right]$ at a concentration of $3.7 \mu \mathrm{g} / \mathrm{mL}$. The concentrations of 1.5 and $7.4 \mu \mathrm{g} / \mathrm{mL}$ of this complex, exhibited decreasing the significant $(\mathrm{p}<0.01$ ), frequency of MN by $40 \%$, when compared with the control cell cultures.

Table-3: Incidence of MN, Cytokinesis-Block Proliferation Index, Distribution MN per cells and Frequency of MN, Measurement in Cell Cultures of Human Lymphocytes Treated with Different Concentration of the

\begin{tabular}{|c|c|c|c|c|c|}
\hline \multicolumn{6}{|c|}{ Complex } \\
\hline $\begin{array}{l}\text { Concentrations } \\
(\mu \mathrm{g} / \mathrm{mL})\end{array}$ & $\begin{array}{l}\text { MN/1000 } \\
\text { Bn cells }\end{array}$ & $\begin{array}{l}\% \text { Bn cell } \\
\text { with MN }\end{array}$ & $\begin{array}{l}\mathrm{MN} / \mathrm{Bn} \\
\text { cell }\end{array}$ & CBPI & $\begin{array}{c}\text { Frequency } \\
\text { of MN }\end{array}$ \\
\hline Control & $24.00 \pm 1.82$ & $1.91 \pm 0.17$ & $1.26 \pm 0.05$ & $1.64 \pm 0.03$ & $100.00 \%$ \\
\hline Amifostin & \multirow{2}{*}{$19.69 \pm 0.85$} & \multirow{2}{*}{$1.56 \pm 0.10$} & \multirow{2}{*}{$1.27 \pm 0.05$} & \multirow{2}{*}{$1.97 \pm 0.03$} & \multirow{2}{*}{$82.04 \%$} \\
\hline$(1.0 \mu \mathrm{g} / \mathrm{mL})$ & & & & & \\
\hline $\mathrm{Na}\left[\mathrm{RuCl}_{2} \mathrm{~L}_{2}\right]$ & \multirow{2}{*}{$14.34 \pm 0.99^{\mathrm{a}, \mathrm{b}}$} & \multirow{2}{*}{$1.34 \pm 0.06$} & \multirow{2}{*}{$1.09 \pm 0.01$} & \multirow{2}{*}{$1.69 \pm 0.05$} & \multirow{2}{*}{$59.8 \%$} \\
\hline$(1.5 \mu \mathrm{g} / \mathrm{mL})$ & & & & & \\
\hline $\mathrm{Na}\left[\mathrm{RuCl}_{2} \mathrm{~L}_{2}\right]$ & \multirow{2}{*}{$13.38 \pm 1.89^{\mathrm{a}, \mathrm{b}}$} & \multirow{2}{*}{$1.24 \pm 0.13$} & \multirow{2}{*}{$1.07 \pm 0.05$} & \multirow{2}{*}{$1.56 \pm 0.05$} & \multirow{2}{*}{$55.8 \%$} \\
\hline$(3.7 \mu \mathrm{g} / \mathrm{mL})$ & & & & & \\
\hline $\begin{array}{l}\frac{\mathrm{Na}\left[\mathrm{RuCl}_{2} \mathrm{~L}_{2}\right]}{(7.4 \mu \mathrm{g} / \mathrm{mL})} \\
\end{array}$ & $14.53 \pm 1.41^{a, b *}$ & $1.21 \pm 0.14$ & $1.21 \pm 0.06$ & $1.75 \pm 0.08$ & $60.5 \%$ \\
\hline
\end{tabular}

MN/1000 Bn cells - incidence of micronuclei in 1000 binucleated cells; \% Bn cells witch micronuclei; MN/Bn cells - the incidence of micronuclei in binucleated cells; CBPI- cytokinesis-block proliferation index; Frequency of MN: incidence of MN presented as \% from control groups in cell cultures of human lymphocytes treated with different concentration of complex. The statistical significance of the difference between the data pairs was evaluated by analysis of variance (One-way ANOVA) followed by the Tukey test. Statistically, the difference was considered significant at $\mathrm{p}<0$. Compared with control groups, statistically significant difference $\mathrm{p}<0.01$.

b Compared with amifostine - WR 2721, statistically significant difference $\mathrm{p}<0.01$.

b* Compared with amifostine - WR 2721, statistically significant difference $\mathrm{p}<0.05$.

For the determination of the effect of the tested complex on cell proliferation, cytokinesis-block proliferation index (CBPI) was used. The mean CBPI values and standard errors calculated at different concentrations of the complex were presented in Table-3. Complex CPBI and Amifostin value are comparable and suggested an inhibitory effect on lymphocyte proliferation of tested $\mathrm{Na}\left[\mathrm{RuCl}_{2} \mathrm{~L}_{2}\right]$. In this study, we found that the lower concentration of the complex has a favorable effect on lymphocyte cells culture by decreasing the frequency of MN. Our results afford the indication of protective effects of the tested complex on cytogenetic and damages in human lymphocytes treated in vitro.

\section{CONCLUSION}

The anionic complex compound of $\mathrm{Ru}(\mathrm{III})$ with $\mathrm{N}$-phenyl-5-nitrosalicylideneimine was synthesized. It was found that ligand acts as an anionic bidentate $\mathrm{O}, \mathrm{N}$-donor ligand which is coordinated to the ruthenium through azomethine nitrogen and phenolic oxygen. The evidence for that was detected by 
analyzing shifts of imines nitrogen toward lower frequency and ones of phenolic oxygen to a higher frequency in the IR spectra of the synthesized complex. The assumed formula of molecular ion $\left[\mathrm{C}_{26} \mathrm{H}_{18} \mathrm{CL}_{2} \mathrm{~N}_{4} \mathrm{O}_{6} \mathrm{Ru}\right]^{-}$, was confirmed in the mass spectrum of the complex, m/z: 653.9641 . For Grampositive bacteria (S. aureus ATCC 33591 and ATCC 29213), the antibacterial activity of the complex was higher than the one of the ligands alone, whereas against the Gram-negative bacteria $(P$. aeruginosa ATCC 27853, E. coli ATCC 25922 and $K$. pneumoniae ATCC 700603) studied compounds were ineffective. MBC confirmed the MIC results for each tested compound and bacterial strain. Also, the antioxidant potential of $\mathrm{Ru}(\mathrm{III})$ complex in peripheral human lymphocytes by using CMBN assay was tested. The cell culture treated with the complex at a concentration of $3.7 \mu \mathrm{g} / \mathrm{mL}$ exhibit the most prominent effect of decreasing the frequency of micronucleus for $44 \%$, while at the concentrations of 1.5 and $7.4 \mu \mathrm{g} / \mathrm{mL}$ effect is slightly lower (40\%), compared to the control cell culture. Synthetic protectors, such as Amifostin WR-2721, used in the treatment of humans, decrease the frequency of MN by about $18 \%{ }^{38}$ The results of this study are essential given Amifostin.

\section{REFERENCES}

1. G. Ceyhan, M. Köse, M. Tümer and İ. Demirtaş, Spectrochimica Acta Part A: Molecular and Biomolecular Spectroscopy, 149, 731 (2015), DOI: 10.1016/j.saa.2015.05.021

2. G. Venkatachalam and R. Ramesh, Inorganic Chemistry Communications, 9(7), 703 (2006), DOI: 10.1016/j.inoche.2006.04.012

3. A.M. Yimer, Review of Catalysts, 2(1), 14 (2015), DOI: 10.18488/journal.96/2015.2.1/96.1.14.25

4. F.S. Alassbaly, A.A. Maihub, S.F. Ben-Gweirif, M.M. El-Ajaily and T.H. Al-Noor, Saudi Journal of Pathology and Microbiology, 1(2), 29 (2016), DOI:10.21276/sjpm.2016.1.2.1

5. M.S. Hossain, P.K. Roy, C.M. Zakaria and M.K. E-Zahan, International Journal of Chemical Studies, 6(1), 19 (2018).

6. N.K. Kar, M.K. Singh and R.A. Lal, Arabian Journal of Chemistry, 10(1), S76 (2017), DOI: 10.1016/j.arabjc.2012.05.007

7. S. Pattanaik, S.S. Rout, J. Panda, P.K. Sahu and M. Banerjee, Rasayan J. Chem., 4(1), 136 (2011).

8. D. Gambino, Curr. Med. Chem., 17(31), 3616 (2010), DOI: 10.2174/092986710793213797

9. A. Cipurković, E. Horozić, N. Ljubijankić, A. Odobašić, S. Galijašević and M. Saletović, Rasayan J. Chem., 10(4), 1381 (2017), DOI: 10.7324/RJC.2017.1041905

10. H.K. Thompson and C. Orvig, Dalton T., 761 (2006), DOI: 10.1039/b513476e

11. N. Padma Priya, S. Arunachalam, A. Manimaran, D. Muthupriya and C. Jayabalakrishnan, Spectrochimica Acta Part A: Molecular and Biomolecular Spectroscopy, 72, 670 (2009), DOI: 10.1016/j.saa.2008.10.028

12. F. Li, J.G. Collins and F.R. Keene, Chem. Soc. Rev., 44, 2529 (2015), DOI: 10.1039/c4cs00343h

13. N. Dharmaraj, P. Viswanathamurthi and K. Natarajan, Transition Metal Chemistry 26, 105 (2001), DOI:10.1023/A:1007132408648.

14. P.S. Chittilappilly and M.K.K. Yusufi, Indian Journal of Chemistry, 47A, 848 (2008).

15. N. Thilagavathi, A. Manimaran and C. Jayabalakrishnan, Journal of Coordination Chemistry, 63(7), 1252 (2010), DOI: 10.1080/00958971003735440

16. I.P. Ejidikea and P.A. Ajibadea, Journal of Coordination Chemistry, 68(14), 2552(2015), DOI: $10.1080 / 00958972.2015 .1043127$

17. T. Jurca, E. Marian, L.G. Vicaş, M.E. Mureşan and L. Fritea, 2017, Metal Complexes of Pharmaceutical Substances, in: E. Sharmin and F. Zafar (Eds.), Spectroscopic Analyses Developments and Applications, In Tech, pp. 24-125, DOI: 10.5772/65390

18. N. Ljubijankić, M. Stanković, V. Tešević, S. Grgurić-Šipka, M. Jadranin, S. Begić, and E. Šabanović, Rasayan J. Chem, 11(2), 647 (2018), DOI: 10.7324/RJC.2018.1123004

19. A. Goszczyńska, H. Kwiecień and K. Fijałkowski, Med Chem Res., 24(9), 3561 (2015), DOI: 10.1007/s00044-015-1397-6 
20. I. Roca, M. Akova, F. Baquero, J. Carlet, M. Cavaleri, S. Coenen, J. Cohen, D. Findlay, I. Gyssens, O.E. Heuer, G. Kahlmeter, H. Kruse, R. Laxminarayan, E. Liébana, L. López-Cerero, A. MacGowan, M. Martins, J. Rodríguez-Baño, J.-M. Rolain, C. Segovia, B. Sigauque, E. Tacconelli, E. Wellington, J. Vila, New Microbes and New Infections, 8, 22 (2015), DOI: 10.1016/j.nmni.2015.02.007

21. A. Blagus, D. Cinčić, T. Friščić, B. Kaitner and V. Stilinović, Maced. J. Chem. Chem. Eng., 29(2), 117 (2010).

22. N. Ljubijankić, A. Zahirović, E. Turkušić and E. Kahrović, Croatica Chemica Acta, 86(2), 215 (2013), DOI: $10.5562 / \mathrm{cca} 2216$

23. N. Beynek, G. Uluçam, BA Tüylü, H. Zeytinoğlu and K. Benkli, Drug Chem Toxicol, 30(4), 399 (2007),_ DOI: 10.1080/01480540701522601

24. A. Damati, D. Vlastos, A.I. Philippopoulos and D.P.Matthopoulos, Global NEST Journal, 17(3), 574 (2015).

25. M. Fenech, W.P. Chang, M. Kirsch-Volders, N. Holland, S. Bonassi and E. Zeiger, Mutat. Res., 34, 65 (2003), DOI:10.1016/S1383-5718(02)00249-8

26. M. Yu Sinitsky and V.G. Druzhinin, Journal of Radiation Research, 55(1), 61 (2014), DOI: 10.1093/jrr/rrt091

27. G. Speit, Mutagenesis, 28(4), 375 (2013), DOI: 10.1093/mutage/get026

28. E. Yesilada, I. Sahin, H. Ozcan, I. Yildirim, S. Yologlu and C. Taskapan, Eur J. Endocrinol., 154, 563 (2006), DOI: 10.1530/eje.1.02117

29. J.M. Andrews, Journal of Antimicrobial Chemotherapy, 48, Suppl. S1, 5 (2001).

30. M. Balouir, M. Sadiki and S.K. Ibnsouda, Journal of Pharmaceutical Analysis, 6, 71 (2016), DOI: 10.1016/j.jpha.2015.11.005

31. Fenech M., Mutat. Res., 455(1-2), 81 (2000), DOI: 10.1016/S0027-5107(00)00065-8

32. Law on Health Care, Official Gazette of the Republic of Serbia, Parliament of the Republic of Serbia, 2005. 107, 112.

33. M. Fenech, Mutat. Res., 285, 35 (1993), DOI: 10.1016/0027-5107(93)90049-L

34. M. Stanković, V. Tešević, V. Vajs, N. Todorović, S. Milosavljević and D. Gođevac, Planta Med., 74, 730 (2007), DOI: 10.1055/s-2008-1074521

35. P.I. Countryman and J.A. Heddle, Mutat. Res., 41, 321 (1976), DOI: 10.1016/0027-5107(76)901056

36. J. Surralles, N. Xamena, A. Creus, J. Catalan, H. Norppa and R. Marcos, Mutat. Res., 341, 169 (1995), DOI: 10.1016/0165-1218(95)90007-1

37. F. Marzatico, C. Porta, M. Moroni, et al., Cancer Chemother Pharmacol, 45, 172 (2000), DOI: https://doi.org/10.1007/s002800050026

38. P.I. Kumar and H.C. Goel, Indian J. Exp. Biol., 38, 1003 (2000).

[RJC-5021/2018] 